\title{
Research on Vertical Bearing Capacity of Pile Foundation under Wave Scouring
}

\author{
Xinyue Wang \\ Shanghai Maritime University, Shanghai, China \\ Email: wangxinyue197@126.com
}

How to cite this paper: Wang, X.Y. (2021) Research on Vertical Bearing Capacity of Pile Foundation under Wave Scouring. Open Journal of Modelling and Simulation, 9, 124-134.

https://doi.org/10.4236/ojmsi.2021.92008

Received: March 19, 2021

Accepted: April 12, 2021

Published: April 15, 2021

Copyright ( 2021 by author(s) and Scientific Research Publishing Inc. This work is licensed under the Creative Commons Attribution International License (CC BY 4.0).

http://creativecommons.org/licenses/by/4.0/

(c) (i) Open Access

\begin{abstract}
In order to analyze the influence of wave scouring on the vertical bearing behavior of the pile foundation, the finite element software ABAQUS was used to simulate the force of the pile foundation under the action of wave scouring. A three-dimensional finite element calculation model of the pile foundation was established according to the actual working conditions, and the calculation results were compared with the field test results to verify the correctness of the built model. Then, the influence of wave scouring depth and pile embedding depth on the vertical bearing behavior of pile foundation was analyzed through calculation examples. The analysis results showed that the greater the depth of wave erosion, the greater the impact on the vertical bearing behavior of the pile foundation. Meanwhile, the smaller the buried depth of the pile body, the greater the impact on the vertical bearing capacity of the pile. Thus, the reduction rate of the vertical bearing capacity under different scouring depths was obtained.
\end{abstract}

\section{Keywords}

Vertical Bearing Capacity, Partially Embedded Piles, Wave Erosion, Erosion Depth, ABAQUS

\section{Introduction}

Nowadays, pile foundation is one of the most widely used foundation forms in marine engineering with a long history. In Marine engineering, wave loads cause soil erosion around piles and form local scour pits, which leads to the decrease of bearing capacity or even destruction of pile foundation, thus reducing the safety of the structure. The problem of the piles foundation scouring has attracted the attention of scholars. However, their researches mainly focus on the erosion effect of water flow on the pile foundation [1], as well as the determination of the 
scouring depth and scope [2] [3]. Since the erosion effect cannot be accurately predicted before the construction, while the actual engineering is often more concerned about the changes in the bearing behavior of the pile foundation after the erosion. Thus, some scholars chose to use finite element methods to simulate the changes in the bearing behavior of the pile foundation. Wei Yuan [4] used the finite element software ABAQUS to analyze the influence of soil weakening around pile on vertical bearing capacity under the cyclic wave load. Ruifang Duan [5] used numerical simulation software to analyze the vertical bearing capacity from the perspective of soil. Hailong Tian [6] used MARC finite element software to analyze the vertical bearing capacity of pile foundations with different pile lengths, diameters and slopes under the action of mountain torrents; Yang Gao [7] established a three-dimensional solid model with the finite element software ABAQUS and carried out an in-depth study on the river scouring problem of pile foundation and pile group foundation. Most of these researches were based on the analysis of the soil erosion state. Scholars in this field have not further studied the relationship between the depth of the erosion pit and the vertical bearing capacity. However, in marine engineering, the changes of wave factors directly lead to the variation of the depth of local scour pits formed by soil around piles. Therefore, the relationship between scour pit depth and vertical bearing capacity needs to be further studied.

In this paper, the finite element software numerical method is used to numerically simulate the force of a partially embedded single pile under vertical load by the ABAQUS software, and the numerical simulation calculation results are compared with the field test results to verify the effectiveness and accuracy of the modeling method. Moreover, the influence of the vertical bearing behavior of partially embedded single pile under different wave scouring depth and different embedment depth is analyzed under different working conditions, which provides a certain reference for similar research.

\section{Finite Element Model}

\subsection{Model Parameter Selection}

The soil parameters were selected according to references [8] [9] (Table 1). The model used concrete piles for simulation. The pile diameter is $1 \mathrm{~m}$, the pile length is $85.4 \mathrm{~m}$, and the buried depth is $51.7 \mathrm{~m}$. The elastic modulus of the pile is $3.15 \times 10^{4} \mathrm{MPa}$, and the Poisson's ratio is 0.25 , which is simulated by a linear elastic model. The soil is simulated by Mohr-Coulomb constitutive model, the model is a three-dimensional solid model, and the size of the numerical model (length $\times$ width $\times$ depth) is $60 \mathrm{~m} \times 30 \mathrm{~m} \times 50 \mathrm{~m}$.

\subsection{Model Processing}

In this paper, the ABAQUS software uses version 6.14, the pile body adopts the linear elastic body constitutive model and the contact between the side of the pile and the soil around the pile is simulated using the Mohr-Coulomb constitutive 
Table 1. Soil parameters.

\begin{tabular}{cccccc}
\hline $\begin{array}{c}\text { Serial } \\
\text { number }\end{array}$ & Soil layer name & Density $/\left(\mathrm{kg} / \mathrm{m}^{3}\right)$ & $\begin{array}{c}\text { Elastic } \\
\text { Modulus/(MPa) }\end{array}$ & Cohesion/(kPa) & $\begin{array}{c}\text { Friction } \\
\text { Angle } /\left(^{\circ}\right)\end{array}$ \\
\hline 1 & Silty clay & 1840 & 0.64 & 20 & 18 \\
2 & $\begin{array}{c}\text { Silt silty clay with } \\
\text { sandy silt }\end{array}$ & 1770 & 0.82 & 10 & 22.5 \\
3 & Mucky clay & 1670 & 0.62 & 14 & 11.5 \\
4 & clay & 1760 & 0.98 & 16 & 14.0 \\
5 & Silty clay & 1840 & 1.34 & 15 & 22.0 \\
6 & Silty clay & 1980 & 3.08 & 45 & 17.0 \\
7 & Sandy clay with silt & 1870 & 12.33 & 3 & 32.5 \\
\hline
\end{tabular}

model. The friction coefficient of tangential contact is $0.3 \tan \varphi$, where $\varphi$ is the internal friction angle of the soil layer; the normal contact uses hard contact, which means that slippage or separation can occur after contact. In order to ensure the rationality of the interaction force transfer between pile and soil, the binding constraint (tie) is adopted between pile bottom and soil.

Considering that the main research object and the deformation position is the pile, in order to make full use of computer resources and improve the calculation efficiency, the area near the pile is meshed, while the area far away from the pile is gradually thinning. The mesh is divided by the 8-node three-dimensional reduction unit C3D8R. The scoured soil is simplified into a regular figure, and the meshing of the finite element model is shown in Figure 1. The outer boundary of the soil constrains the two horizontal displacements of U1 and U2, and the bottom of the model only constrains the vertical displacement of U3.

\section{Model Loading and Verification}

In the finite element calculation and analysis, the initial ground stress of the soil has a great influence on the calculation results. Thus, after the model is established, the ground stress balance calculation must be performed first. After the ground stress is balanced, a load of $4000 \mathrm{kN}$ is applied to the top of the pile to obtain the displacement-settlement curve of the soil before being affected by wave erosion as shown in Figure 2. At this time, the pile displacement calculated by the established ABAQUS analysis model is compared with the field measured value, as shown in Figure 2. From the figure, it can be seen that the results calculated by the finite element software are in good agreement with the field test results, indicating the meta-results can reflect the true characteristics of the pile.

\section{Model Introduction and Calculation Conditions}

\subsection{Model Introduction}

A three-dimensional finite element model of a single pile partially embedded in a single-layer foundation is established. The pile-soil parameters are shown in Table 2. The pile diameter $\mathrm{D}=1.4 \mathrm{~m}$, the total length of the pile is $37 \mathrm{~m}$, and the 

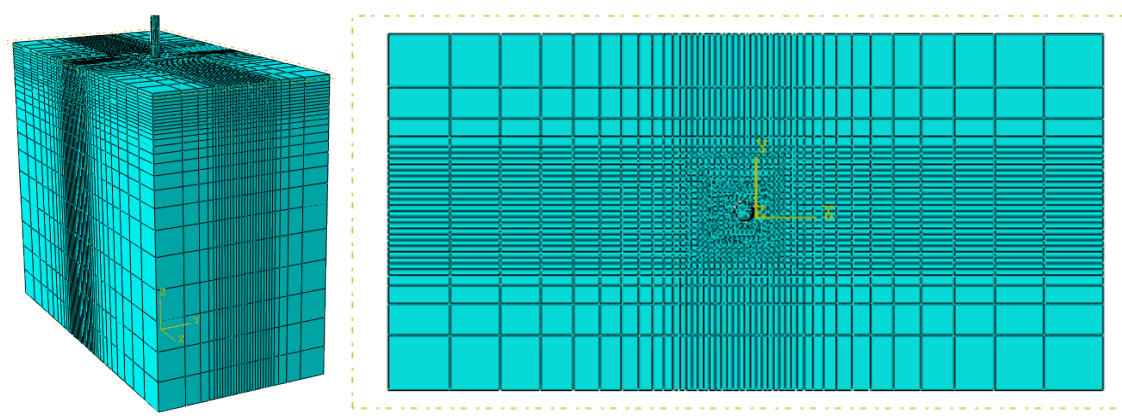

Figure 1. Model meshing.

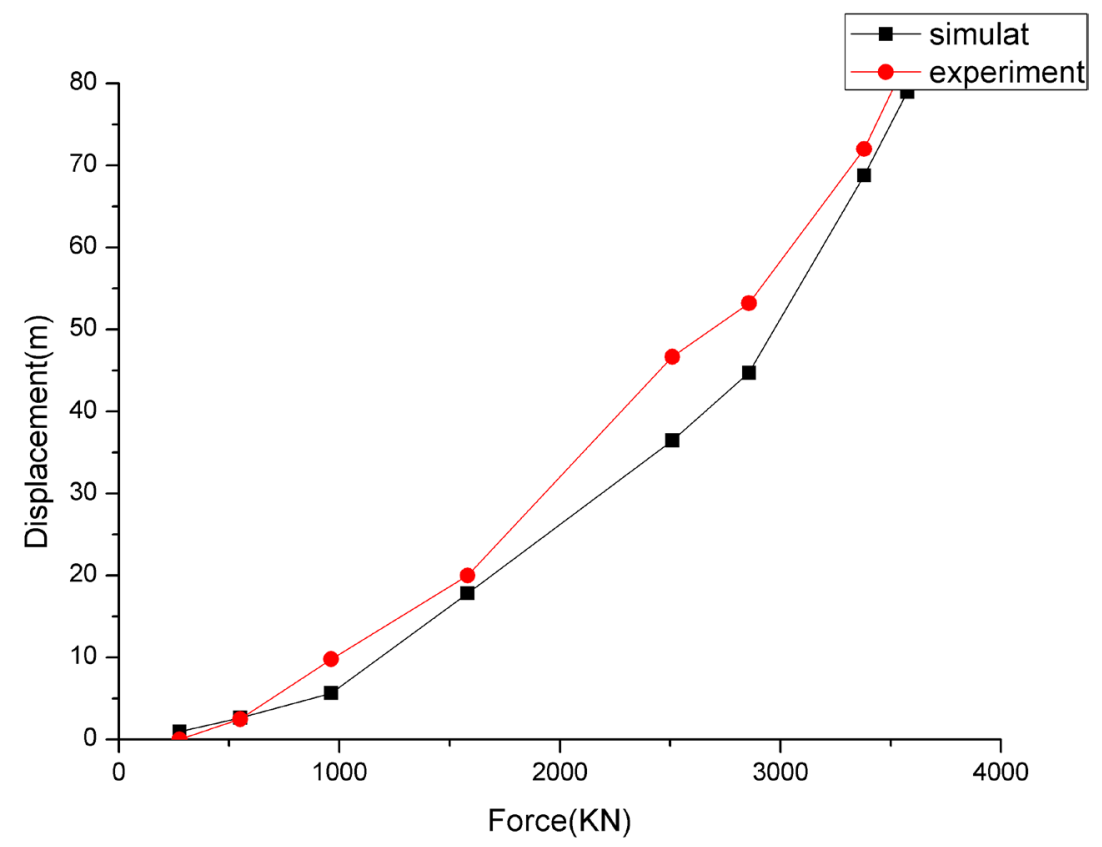

Figure 2. Verification of pile displacement.

Table 2. Parameters of pile and soil for numerical model.

\begin{tabular}{ccccccc}
\hline Material & $\begin{array}{c}\text { Density/ } \\
\left(\mathrm{kg} / \mathrm{m}^{3}\right)\end{array}$ & $\begin{array}{c}\text { Cohesion/ } \\
(\mathrm{Pa})\end{array}$ & $\begin{array}{c}\text { Friction } \\
\text { Angle } /\left(^{\circ}\right)\end{array}$ & $\begin{array}{c}\text { Dilation } \\
\text { Angle } /\left(^{\circ}\right)\end{array}$ & $\begin{array}{c}\text { Elastic } \\
\text { Modulus/(Pa) }\end{array}$ & $\begin{array}{c}\text { Poisson's } \\
\text { ratio }\end{array}$ \\
\hline Soil & 1800 & 80,000 & 20 & 0 & $10 \mathrm{e} 6$ & 0.2 \\
pile & 2400 & - & - & - & $31,500 \mathrm{e} 6$ & 0.3 \\
\hline
\end{tabular}

pile depth is $\mathrm{L}=30 \mathrm{~m}, \mathrm{~L}=20 \mathrm{~m}$, and $\mathrm{L}=10 \mathrm{~m}$. The three-pile embedment depth setting conditions analyze the influence of scouring on the vertical bearing capacity of the pile foundation. Because of the complexity of wave scouring process, the impact of scouring is mainly reflected in the contact part between soil and pile foundation. Since it has no significant relationship with the properties of scour pit, the scour pit shape is simplified into regular cuboids in the finite element analysis, while the process of wave scour is simulated by using the function of life and death unit of ABAQUS to remove the soil at the corresponding depth step by step at a unit of $0.5 \mathrm{~m}$ depth. Figure 3 is the local scour diagram of a 


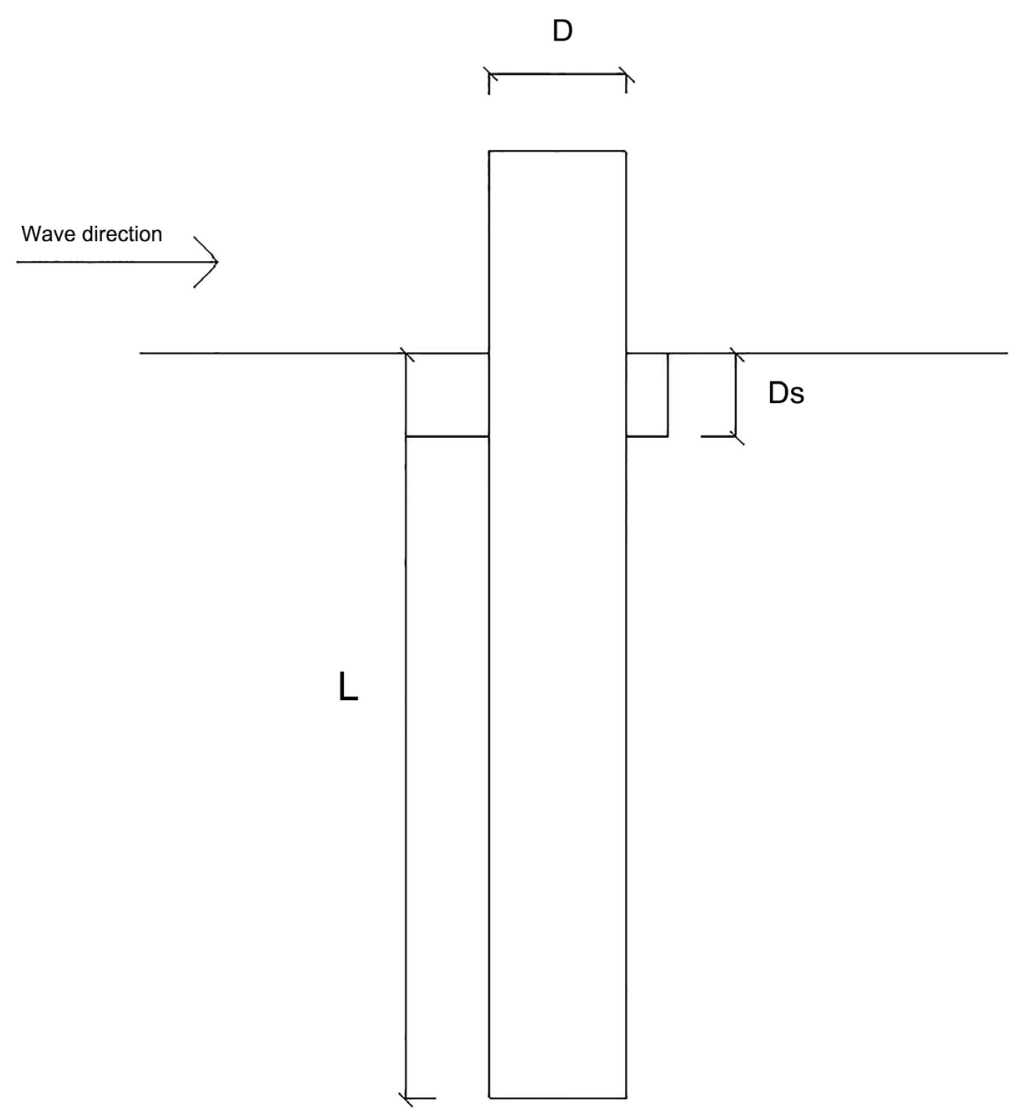

Figure 3. Sketch of partial erosion.

partially embedded single pile. Ds is the scour depth, D is the pile diameter, and $\mathrm{L}$ is the depth of the pile. (The erosion is more serious in the direction of incoming wave, so the soil is missing more)

\subsection{Calculation Condition}

The main research object of this paper is the vertical ultimate bearing capacity, and the load settlement curve of pile foundation (i.e. P-S curve) can directly reflect the stress characteristics of pile. Meanwhile, this curve can directly reflect the pile lateral friction, the load transfer characteristics of pile-soil system and the performance of pile tip resistance. According to the relevant literature, the settlement amount is $3 \%$ to $6 \%$ of the pile diameter, and the recommended value is $40 \mathrm{~mm}-60 \mathrm{~mm}$, referring to the Literature [10] Appendix Q, Article 8. In marine engineering, foundation settlement is very sensitive and important to the structure, so the ultimate bearing capacity is taken as the P-S curve of pile foundation, and the settlement is the corresponding load of $40 \mathrm{~mm}$.

\section{Calculation Result Analysis}

\subsection{The Effect of Scouring Depth on the Vertical Bearing Properties of Partially Embedded Single Piles}

In order to explore the influence of scouring depth, the following seven working 
conditions were set for calculation: the scouring depth was $0 \mathrm{~m}, 0.5 \mathrm{~m}, 1 \mathrm{~m}, 1.5$ $\mathrm{m}, 2 \mathrm{~m}, 2.5 \mathrm{~m}, 3 \mathrm{~m}$, respectively; The remaining parameters were $\mathrm{D}=1.4 \mathrm{~m}$ and $\mathrm{L}=30 \mathrm{~m}$. A pile top load of $5000 \mathrm{kN}$ was applied to each working condition.

Figure 4 shows that the overall vertical bearing capacity of the pile foundation is related to the scouring depth. With the increase of scour depth, the vertical displacement of the pile top gradually increases. This is mainly because the erosion of the soil around the pile caused by wave erosion, which weakens the shear strength provided by the soil around the pile, while the overall vertical stiffness of the pile foundation gradually decreases with the increase of scour depth In addition, as shown in Figure 5, with the increase of the pile top load, the vertical

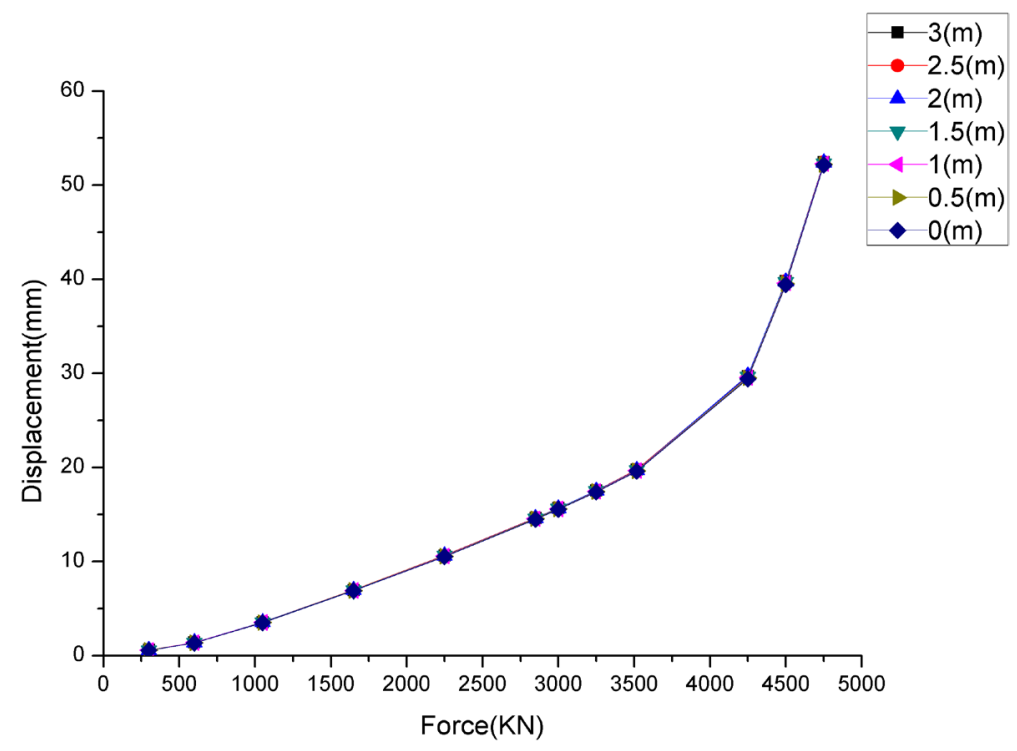

Figure 4. Load-settlement curve of $30 \mathrm{~m}$ buried depth.

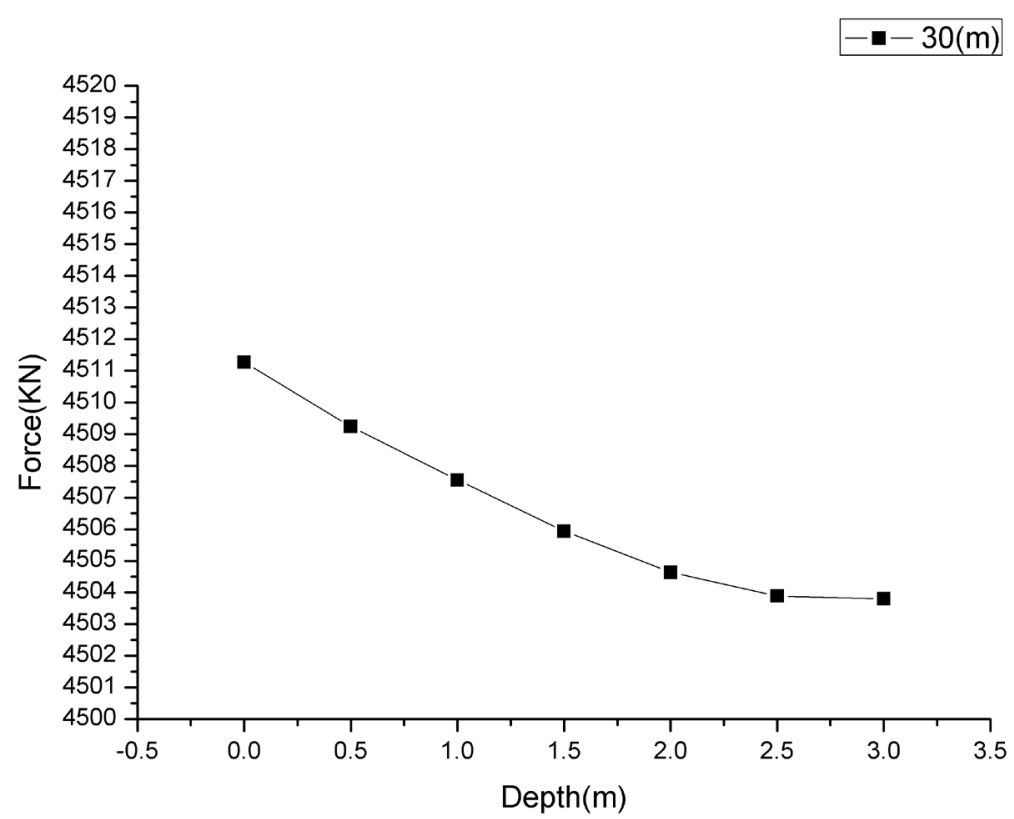

Figure 5. Curve of ultimate bearing capacity of $30 \mathrm{~m}$ buried with erosion depth. 
ultimate bearing capacity of the pile foundation decreases with the increase of the scouring depth, and the trend of bearing capacity gradually slows down with the increase of the scouring depth.

\subsection{The Influence of Pile Embedding Depth on the Vertical Bearing Behavior of Single Pile}

In order to explore the influence of pile embedment depth, the following three working conditions were set for calculation: the pile embedment depth was 30 $\mathrm{m}, 20 \mathrm{~m}$, and $10 \mathrm{~m}$, respectively; the remaining parameters were: $\mathrm{D}=1.4 \mathrm{~m}$. A pile top load of $5000 \mathrm{KN}$ was applied to each working condition.

As shown in Figure 6, starting from the load of $2500 \mathrm{kN}$, the curve trends of the three different burial depths are obviously distinct, which indicates that when the pile is not scoured by waves, the displacement of the pile top increases significantly with the decrease of the embedded depth of the pile. The main reason is that the contact area between pile and soil becomes smaller when the depth of embedding decline, which leads to the decrease of pile lateral friction resistance. Therefore, as the resistance to lateral deformation decreases, the ultimate vertical bearing capacity of the pile also reduces.

\subsection{Influence of Pile Embedment Depth on Vertical Bearing Behavior of Single Pile under the Influence of Wave Scouring Depth}

In order to explore the influence of pile embedment depth on vertical bearing capacity under the change of wave scouring depth, the in-depth calculations were carried out according to three different pile embedment depths: the pile embedment depth were $30 \mathrm{~m}, 20 \mathrm{~m}$, and $10 \mathrm{~m}$; the scour depth were $0 \mathrm{~m}, 0.5 \mathrm{~m}$, $1 \mathrm{~m}, 1.5 \mathrm{~m}, 2 \mathrm{~m}, 2.5 \mathrm{~m}, 3 \mathrm{~m}$; the remaining parameters were $\mathrm{D}=1.4 \mathrm{~m}$. A 4000 $\mathrm{KN}$ pile top load was applied to each working condition.

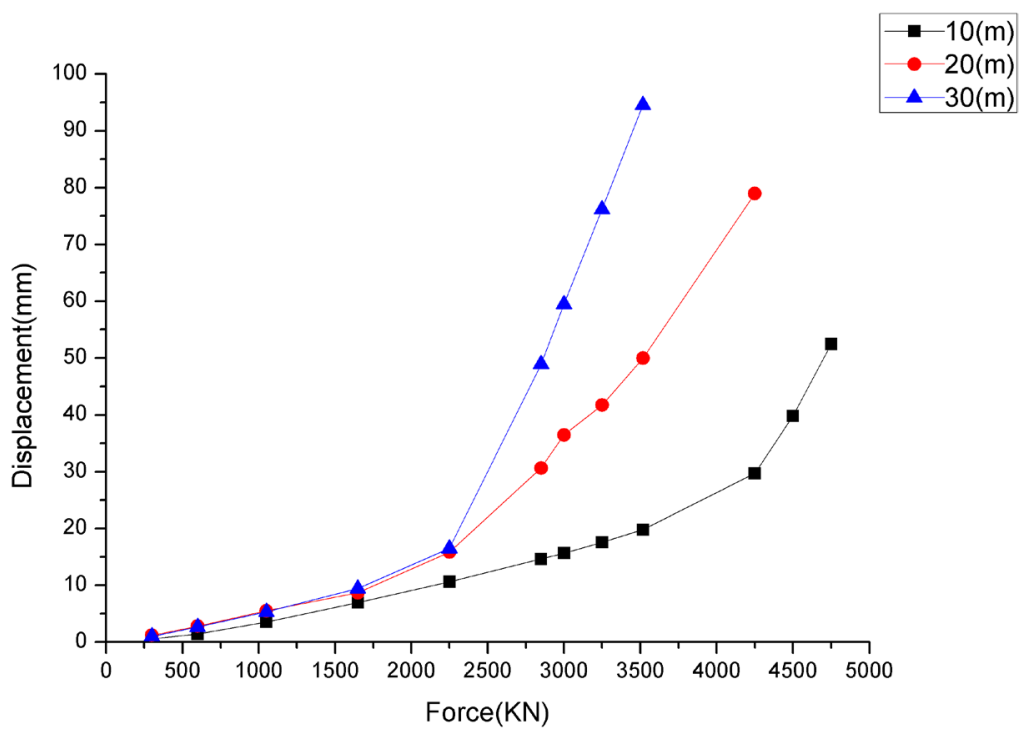

Figure 6. Load-settlement curves of different pile depths. 
As shown in Figure 7 and Figure 8, the settlement curve trend of piles buried with a depth of $20 \mathrm{~m}$ and $10 \mathrm{~m}$ is consistent with that of piles buried with a depth of $30 \mathrm{~m}$. This indicates that the displacement of pile top increases with the decrease of scour depth, which is influenced by wave scouring. As the erosion depth decreases, it is obvious that the smaller the embedding depth is, the more obvious the bearing capacity decreases. This is mainly due to the erosion of the

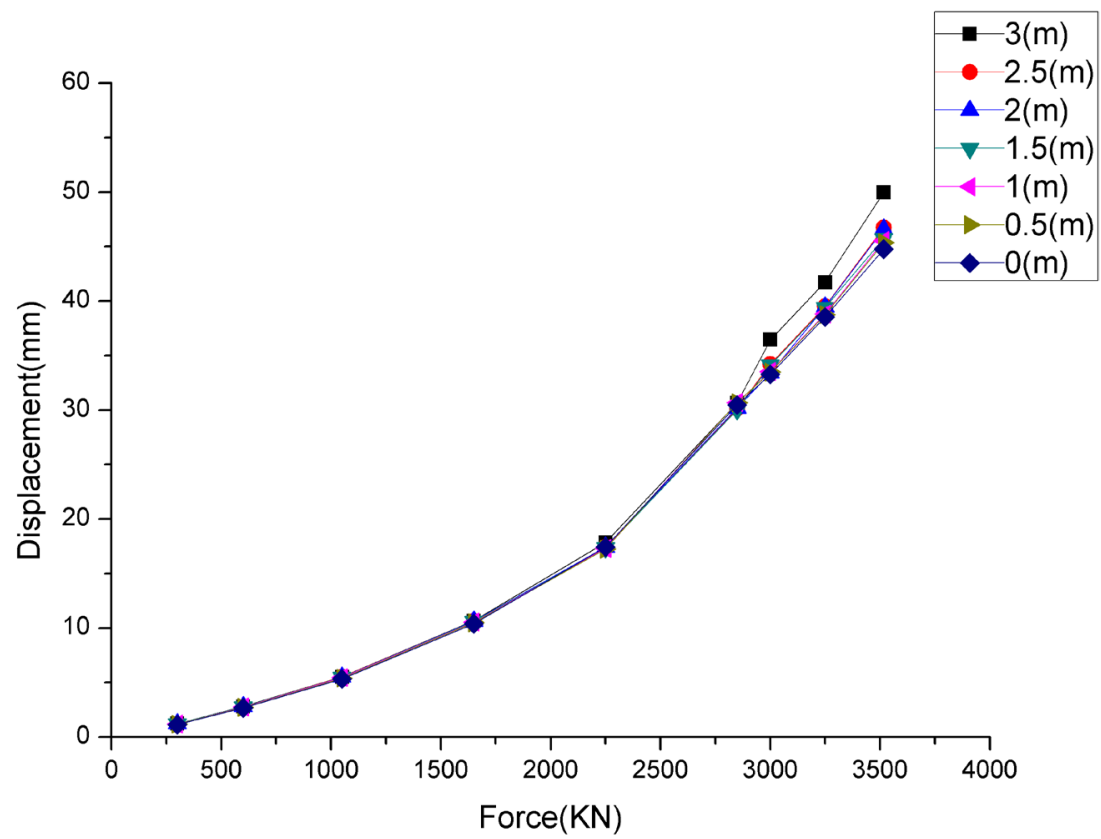

Figure 7. Load-settlement curve of piles embedded at a depth of $20 \mathrm{~m}$ affected by wave scouring.

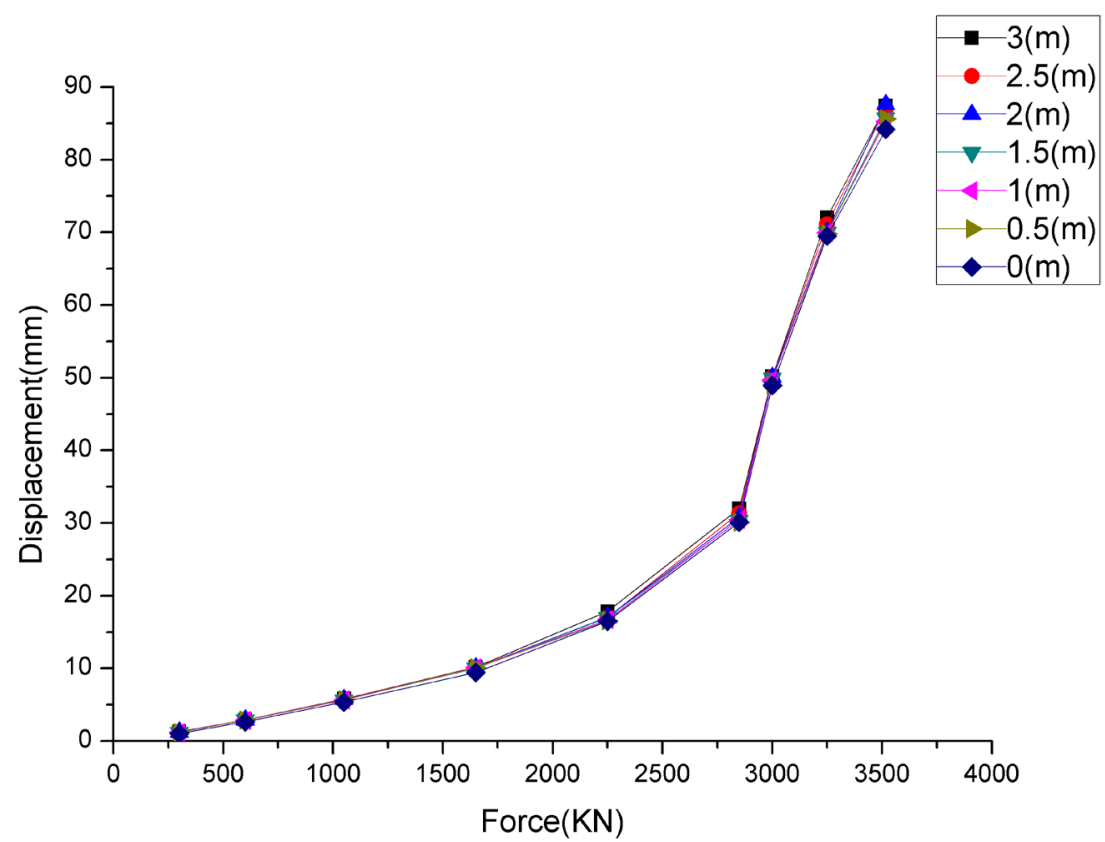

Figure 8. Load-settlement curve of piles embedded at a depth of $10 \mathrm{~m}$ affected by wave scouring. 
soil around the pile and the decrease of the buried depth of the soil caused by wave erosion, both of which make the contact area between the pile and soil become smaller. As the side friction of the smaller pile decreases, the vertical bearing capacity of the pile also declines. When the pile is buried $10 \mathrm{~m}$ and the scour depth is $1.5 \mathrm{~m}$, the bearing capacity of the pile drops sharply. It can be seen that, with the decrease of embedding depth and the increase of scour depth, the vertical bearing capacity has a superimposed effect. Therefore, the scour depth has a greater impact on the pile with a smaller embedding depth.

\subsection{The Reduction Rate of Vertical Bearing Capacity under the Influence of Scouring Depth}

As shown in Table 3, according to the curve of the ultimate bearing capacity versus erosion depth in Figure 9, the reduction rate of the bearing capacity after each scouring is obtained. The variation of vertical ultimate bearing capacity is

Table 3. The loss rate of vertical bearing capacity.

\begin{tabular}{|c|c|c|c|}
\hline scour depth & $30 \mathrm{~m}$ & $20 \mathrm{~m}$ & $10 \mathrm{~m}$ \\
\hline 0.5 & $0.045 \%$ & $0.357 \%$ & $0.004 \%$ \\
\hline 1 & $0.037 \%$ & $0.082 \%$ & $1.045 \%$ \\
\hline 1.5 & $0.036 \%$ & $0.681 \%$ & $1.112 \%$ \\
\hline 2 & $0.029 \%$ & $0.166 \%$ & $0.205 \%$ \\
\hline \multirow[t]{2}{*}{2.5} & $0.017 \%$ & $0.051 \%$ & $0.682 \%$ \\
\hline & $0.002 \%$ & $2.284 \%$ & $0.361 \%$ \\
\hline
\end{tabular}

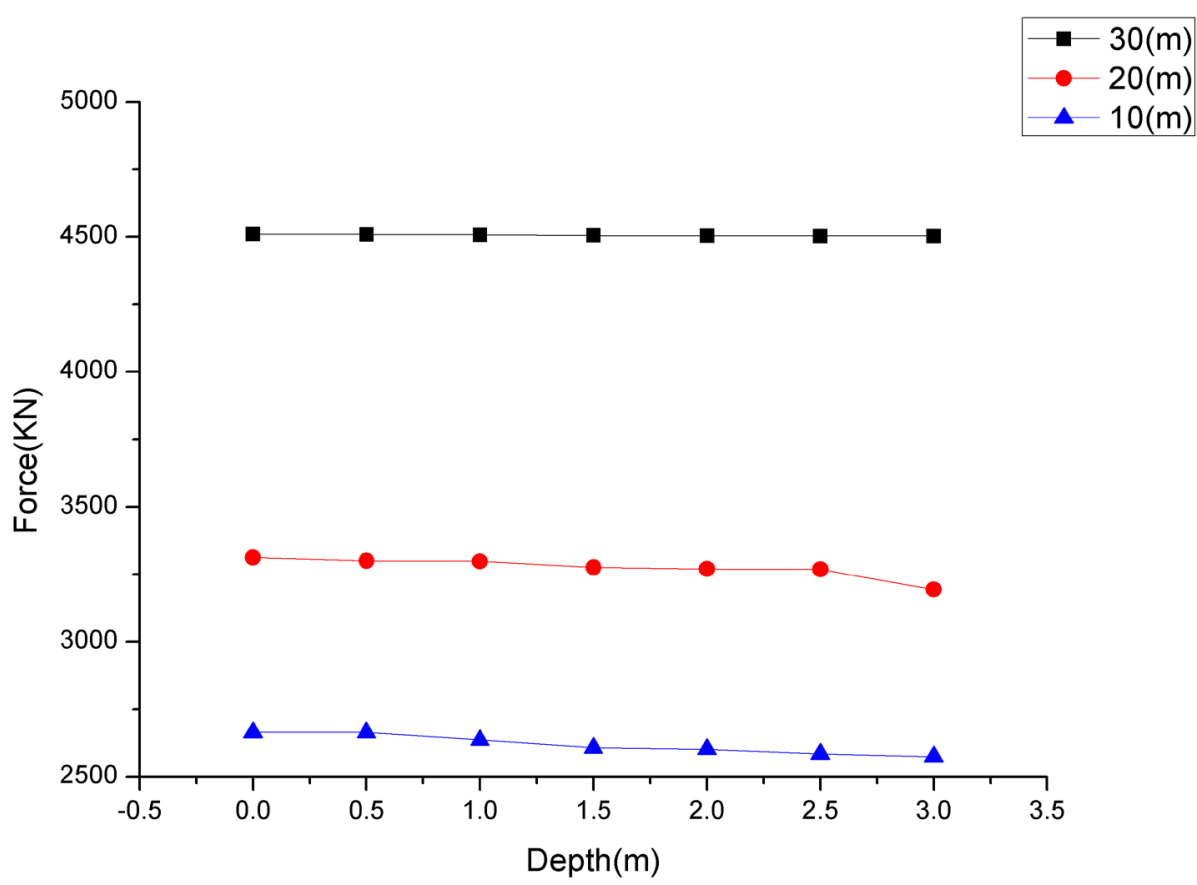

Figure 9. Curve of ultimate bearing capacity versus wave scouring depth. 
Table 4. The loss rate of vertical bearing capacity.

\begin{tabular}{ccc}
\hline scour depth & embedded depth & $10 \mathrm{~m}$ \\
\hline 0 & $26.57 \%$ & $19.57 \%$ \\
0.5 & $26.80 \%$ & $19.28 \%$ \\
1 & $26.83 \%$ & $20.06 \%$ \\
1.5 & $27.31 \%$ & $20.41 \%$ \\
2 & $27.41 \%$ & $20.44 \%$ \\
2.5 & $27.43 \%$ & $20.94 \%$ \\
3 & $29.09 \%$ & $19.39 \%$ \\
\hline
\end{tabular}

different under divergent scour depth. The effect of scour depth on vertical bearing capacity of pile decreases with the increase of scour depth. Among them, the first scouring has the greatest impact on the vertical ultimate bearing capacity of the pile foundation.

\subsection{The Reduction Rate of Vertical Bearing Capacity under the Combined Influence of Scouring Depth and Buried Depth}

As shown in Table 4, comparing the bearing capacity of pile embedded depth 20 $\mathrm{m}$ and $10 \mathrm{~m}$ with the bearing capacity of pile embedded depth $30 \mathrm{~m}$, it is found that the bearing capacity of piles at the depth of $20 \mathrm{~m}$ and $10 \mathrm{~m}$ does not change much with the modification of scour depth, which shows that the decrease in depth of pile embedment will not overlap with the increase in scour depth. However, the reduction of pile embedding depth will increase the bearing capacity loss rate.

\section{Conclusions}

In this study, a validated three-dimensional finite element model was used to simulate the load of pile foundation under wave scouring. The results show that the depth of wave erosion has a great effect on the vertical bearing behavior of partially embedded single pile. In practical engineering, the impact of scouring depth needs to be considered. The displacement of partially embedded piles increases rapidly with the increase of scour depth, resulting in a decrease in the vertical bearing capacity. With the increase of pile depth, the displacement of pile top gradually increases, and the vertical bearing capacity decreases accordingly. When the embedded depth of the pile body decreases and the erosion depth increases, the displacement of pile top increases significantly, and the strength of vertical bearing capacity increases. The variation of the vertical ultimate bearing capacity is different at different scouring depths. The effect of scouring depth on vertical bearing capacity of pile decreases with the increase of scour depth. Among them, the first scouring has the greatest effect on the vertical ultimate bearing capacity of pile foundation.

The soil around the pile foundation is prone to scour under the action of 
waves, which greatly weakens the bearing capacity of the pile foundation. As for pile foundations with relatively shallow initial buried depth, the weakening effect of vertical bearing capacity caused by scouring is particularly significant. Therefore, the depth of the buried pile and the scouring problem should be considered in the project. This article has conducted a deep research on the relationship between the depth of the scouring depth and the vertical bearing capacity, and the obtained the reduction rate can also provide a certain reference for similar research and engineering.

\section{Conflicts of Interest}

The author declares no conflicts of interest regarding the publication of this paper.

\section{References}

[1] Avent, R.R. and Alawady, M. (2005) Bridge Scour and Substructure Deterioration: Case Study. Journal of Bridge Engineering, 10, 247-254. https://doi.org/10.1061/(ASCE)1084-0702(2005)10:3(247)

[2] Sumer, B.M., Freds, E.J. and Christiansen, N. (1992) Scour around a Vertical Pile in Waves. Journal of Waterway, Port, Coastal and Ocean Engineering, 118, 15-31. https://doi.org/10.1061/(ASCE)0733-950X(1992)118:1(15)

[3] Chen, G.P., Zuo, Q.H. and Huang, L.G. (2004) Local Scour around Large-Scale Cylinder under Wave Action. The Ocean Engineering, 22, 46-58.

[4] Yuan, W., Yan, S.W. and Zhao, L. (2011) Influential Study on Wave Loading to Vertical Bearing Capacity of Wharf Pile Foundation. Site Investigation Science and Technology, 6, 1-9.

[5] Duan, R.F., Wang, D. and Wang X.M. (2019) Evaluation Method of Vertical Ultimate Bearing Capacity of Slope Pile Foundation under Scour. Journal of Wuhan University of Technology (Transportation Science and Engineering Edition), 43, 20-25.

[6] Tian, H.L. (2016) Analysis of the Influence of Mountain Torrent Scour on the Vertical Bearing Characteristics of Steep Slope Bridge Pile Foundation. Hunan Communication Science and Technology, 42, 208-213.

[7] Gao, Y. (2015) Numerical Simulation of the Influence of River Scouring on the Vertical Bearing Behavior of Pile Foundations of Existing Bridges. Master's thesis.

[8] Li, T. (2020) Field Tests Research on Bearing Characteristics of Super-Long Piles in Soft Soil Region. Building Structure, 50, 114-120

[9] Detailed Survey Report of Shanghai Tower Project. https://max.book118.com/html/2017/0511/106109618.shtm

[10] Ministry of Construction of the People's Republic of China (2002) Code for Design of Building Foundation: GB 5000-2002. China Architecture \& Building Press, Beijing, China 